\title{
Correction to: Detecting economic insecurity in Italy: a latent transition modelling approach
}

\author{
Francesca Giambona $^{1}$ (D) Laura Grassini $^{1} \cdot$ Daniele Vignoli $^{1}$ \\ Published online: 25 January 2022 \\ (C) The Author(s) 2022
}

\section{Correction to: Statistical Methods \& Applications https://doi.org/10.1007/s10260-021-00609-y}

The article "Detecting economic insecurity in Italy: a latent transition modelling approach", written by Francesca Giambona, Laura Grassini, Daniele Vignoli, was originally published electronically on the publisher's internet portal on 5 January 2022 without open access. With the author(s)' decision to opt for Open Choice the copyright of the article changed on 12 January 2022 to (C) The Author(s) 2022 and the article is forthwith distributed under a Creative Commons Attribution 4.0 International License, which permits use, sharing, adaptation, distribution and reproduction in any medium or format, as long as you give appropriate credit to the original author(s) and the source, provide a link to the Creative Commons licence, and indicate if changes were made. The images or other third party material in this article are included in the article's Creative Commons licence, unless indicated otherwise in a credit line to the material. If material is not included in the article's Creative Commons licence and your intended use is not permitted by statutory regulation or exceeds the permitted use, you will need to obtain permission directly

The original article can be found online at https://doi.org/10.1007/s10260-021-00609-y.

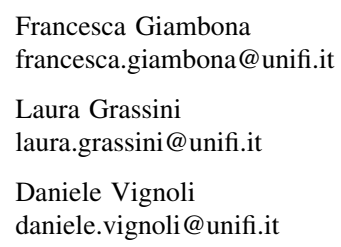

Francesca Giambona

francesca.giambona@unifi.it

Laura Grassini

laura.grassini@unifi.it

Daniele Vignoli

daniele.vignoli@unifi.it

1 Dipartimento di Statistica, Informatica, Applicazioni “G. Parenti”, Università di Firenze, Viale Morgagni, 59, 50134 Florence, Italy 
from the copyright holder. To view a copy of this licence, visit http:// creativecommons.org/licenses/by/4.0/.

Publisher's Note Springer Nature remains neutral with regard to jurisdictional claims in published maps and institutional affiliations. 